SANTOS, PR; MELO, RA; COSTA, KDS; ROCHA, FAT; COSTA, IJN; CARVALHO FILHO, JLS; MENEZES, D. 2017. Combining ability and agronomic performance of sweet pepper in greenhouse. Horticultura Brasileira 35: 026-032. DOI - http://dx.doi.org/10.1590/S0102-053620170105

\title{
Combining ability and agronomic performance of sweet pepper in greenhouse
}

\author{
Paulo R Santos ${ }^{1}$; Roberto A Melo²; Kleyton DS Costa²; Fernando AT Rocha² ${ }^{2}$ Ítalo JN Costa ${ }^{2}$; José LS \\ Carvalho Filho ${ }^{2}$; Dimas Menezes ${ }^{2}$ \\ ${ }^{1}$ Universidade Estadual do Norte Fluminense (UENF), Campos dos Goytacazes-RJ, Brasil; prs_ufal@hotmail.com; ${ }^{2}$ Universidade \\ Federal Rural de Pernambuco (UFRPE), Recife-PE, Brasil; robertoagronomo@yahoo.com.br; kd.agro@gmail.com; fernando-rocha@ \\ r7.com; joseluiz.ufrpe@yahoo.com.br; italojncosta@hotmail.com; dimas@depa.ufrpe.br
}

\begin{abstract}
We aimed to evaluate the combining ability of sweet pepper lines, to identify superior hybrid combinations for fruit productivity and quality, and to infer the gene action involved in the expression of agronomic traits of economic importance. Five sweet pepper lines from the Project Solanaceae Breeding for Production Systems, of the Universidade Federal Rural de Pernambuco were crossed in a partial diallel scheme with two simple hybrids: Atlantis (ATL) and Valdor (VAL), used as testers. Lines and hybrids were selected for the study by presenting different morphological characteristics, such as fruit shape, length and diameter, pulp thickness and productivity. Completely randomized blocks were the experimental design, with four replications and twenty treatments consisting of five lines, two testers, ten experimental hybrids and three commercial hybrids as controls, which were analyzed using the method 2 model I of Griffing, adapted by Geraldi \& Miranda Filho (1988). The authors detected genetic variability enough to be explored in diallel components; for most traits, the additive and non-additive effects were significant and important, showing the performance of genotypes and their contribution for the production of superior hybrids; lines L1B, L6 and L 7 and the tester Valdor stood out as good combiners which presented higher general combining ability for most agronomic traits; the triple hybrid L1B x VAL stood out for the best performance with the best specific combining abilities.
\end{abstract}

Keywords: Capsicum annuum, heterosis, partial diallel.

\section{RESUMO}

Capacidade de combinação e desempenho agronômico de pimentão em cultivo protegido

Objetivou-se avaliar a capacidade combinatória de linhagens de pimentão, identificar combinações híbridas superiores quanto à produtividade e qualidade de frutos e inferir sobre os modos de ação gênica envolvidos na expressão dos caracteres agronômicos de importância econômica. Para isso, cinco linhagens de pimentão do Projeto Melhoramento Genético de Solanáceas Para Sistema de Cultivo, da Universidade Federal Rural de Pernambuco foram cruzadas, em um esquema dialélico parcial, com dois híbridos simples: Atlantis (ATL) e Valdor (VAL), utilizados como testadores. As linhagens, bem como os híbridos utilizados, foram escolhidas em função de apresentarem características morfológicas divergentes, tais como: formato, comprimento e diâmetro do fruto, espessura da polpa e produtividade. O delineamento experimental utilizado foi em blocos casualizados, com quatro repetições, vinte tratamentos, constituídos pelas cinco linhagens, dois testadores, dez híbridos experimentais e três híbridos comerciais como testemunhas, os quais foram analisados através do método 2 do modelo I de Griffing, adaptado por Geraldi \& Miranda Filho (1988). Detectou-se suficiente variabilidade genética a ser explorada nos componentes do dialelo para a maioria dos caracteres; os efeitos aditivos e não-aditivos foram importantes e significativos, mostrando o desempenho dos genótipos e sua contribuição para a produção de híbridos superiores, as linhagens L1B, L6 e L7 e o testador Valdor destacaram-se como bons combinadores por apresentarem maior capacidade geral de combinação para a maioria dos caracteres agronômicos; o híbrido triplo L1B x VAL destacou-se pelo melhor desempenho, com as melhores capacidades específicas de combinação.

Palavras-chave: Capsicum annuиm, heterose, dialelo parcial.

Received on May 17, 2015; accepted on March 17, 2016

$\mathrm{S}$ weet pepper (Capsicum annuum) is among the ten most important vegetable crops in Brazil (Blat et al., 2007). Changes in production systems, such as adoption of adapted cultivars, productive and resistant to diseases, are some of the main reasons for an increase recorded on sweet pepper growing area and productivity (Carvalho et al., 2003).

Obtaining hybrids has been the best strategy towards an imediate effect over productivity and quality of sweet pepper fruits as well as to form a base population in order to select superior lines over segregating generations.

Genetic studies on economicallyrelevant traits must be considered in the context of a breeding program for evaluating the parental line genetic potential for producing good descendants, as well as to increase the 
efficiency of breeding methods, which relies on selecting parents together with information about nature and magnitude of genic effect controlling characters of agronomic interest (Borém \& Miranda, 2013).

Selecting lines for the synthesis of hybrids is one of the key points in sweet pepper breeding, since it enables combining favorable alleles in F1 generation, in order to produce productive and adapted new cultivars (Gomide et al., 2003).

Combining ability is obtained through diallelic crosses, which involves crosses between parents, which allow obtaining estimates of general combining ability (GCA) and specific combining ability (SCA). The GCA analysis enables to identify parents with ability to transmit their desirable characters to offspring, wherein additive gene effects prevail and SCA allows identifying promising hybrid combinations, in which non-additive gene effects prevail (Cruz et al., 2012).

Several kinds of diallels have been proposed and developed, but some of these models have had its use restricted for some species, due to the difficulties in carrying out all possible crosses among available parents for providing the necessary estimates (Holland, 2001). Alternative types were developed, like the partial diallels, which are based on the combination among parents from two different groups. This technique has enabled to maximize the information on the groups studied with a fewer number of crosses than the ones required in the complete diallel (Bernardo, 2003).

Through the estimates of GCA and SCA effects, the best hybrids and the best parents are chosen in order to be used in breeding programs (Nascimento, 2010).

Thus, this work aimed to determine the agronomic potential of triple hybrids, to estimate the relative heterosis and the general and specific combining ability effects in partial diallelic crosses for sweet pepper agronomic characters.

\section{MATERIAL AND METHODS}

Five sweet pepper lines of the project
Solanaceae Breeding for Growing Systems, of Universidade Federal Rural de Pernambuco, Pernambuco State, Brazil, were crossed in partial diallelic scheme, with two simple hybrids: Atlantis (ATL) and Valdor (VAL), as testers. The processes for obtaining triple hybrids began in January, 2013, in a greenhouse. Lines showed squareshaped fruits, thick pulp, many fruits per plant and red-colored fruits, except L6 line which showed yellow fruits. Testers were chosen according to their divergent fruit morphological traits and productivity. Testers presented rectangular-shaped fruits, different fruit size, distinct production per plant and early productivity. The hybrid Valdor belongs to the group of yellow sweet peppers and Atlantis belongs to the red group.

Lines were used as female parents and the testers as male parents. In flowering phase, the authors emasculated lines during the flower-bud stage, pollinating them with pollen collected from testers and then mixed, according to the partial diallelic scheme among five lines and two testers which resulted in ten experimental hybrids forming two triple topcrosses. After pollination, the pollinated flower was identified. Fruits from the crosses were harvested ripe; the seeds were extracted manually, washed in running water and dried in the shade.

For obtaining experimental data, one experiment was carried out from July to December, 2013, in a greenhouse at Departamento de Agronomia (Agronomy Department) of UFRPE, in Recife municipality $\left(8^{\circ} 01^{\prime} 05^{\prime \prime} \mathrm{S}\right.$, $34^{\circ} 56^{\prime} 48^{\prime \prime} \mathrm{W}, 6.49$ m elevation).

The experimental design was randomized blocks, with four replications and twenty treatments consisting of five lines, two testers, ten experimental hybrids obtained and three commercial hybrids used as controls. Each plot consisted of four plants, spaced $1.75 \mathrm{~m}$ between lines and 0.60 $\mathrm{m}$ between plants.

Sowing was carried out into polystyrene trays with 128 cells containing commercial substrate. Seedlings, 35 days after sowing, were transplanted into $5 \mathrm{~L}$ pots containing substrate.
Plants were grown in NFT hydroponic system with substrate and irrigated three times a day with nutrient solution, according to the crop water requirement for each development stage, through a pressurized irrigation system. Therefore, the authors applied nutrient solution up to reaching the pot capacity and leaching begun when the irrigation was stopped immediately.

The authors adopted the nutrient solution adapted from Furlani et al. (1999), for sweet pepper crop. In order to prepare $1000 \mathrm{~L}$ of pre-flowering solution, the authors used $750 \mathrm{~g}$ calcium nitrate, $450 \mathrm{~g}$ potassium nitrate, $200 \mathrm{~g}$ monoammonium phosphate (MAP), 400 g magnesium sulfate, $25 \mathrm{~g}$ Fe chelate (EDDHA-Fe) and $25 \mathrm{~g}$ solid mixtures of EDTA-chelated micronutrients. For fruiting solution, the same fertilizers with their respective doses were used, boric acid being added ( $25 \mathrm{~g}$ of the solid product diluted in $1 \mathrm{~L}$ water, $75 \mathrm{~mL}$ of this solution being used in $1000 \mathrm{~L}$ ) as well as $150 \mathrm{~g}$ monopotassium phosphate (MKP).

The plants were pruned and conducted in system 1-2-4, four branches being kept by the end of the crop cycle. The first flower, located at the first fork, was eliminated. Plants were tutored, in order to make them keep the vertical position and prevent damping-off, through a center cord installed from the base of the plant to the apex. The authors used two ribbons stuck alongside the plants as they were growing.

Fruits were harvested when color began to change, indicating the beginning of physiological maturation, in order to uniform the end of their development. Fruits were harvested from each plot and the average per plant was estimated, nine harvests being carried out all over the experiment.

The agronomic traits evaluated were: fruit diameter (DF); fruit length $(\mathrm{CF})$; fruit length/diameter ratio $(\mathrm{C} / \mathrm{D})$; number of locules per fruit (NL); pulp thickness (EP); number of fruits per plant (NFP); average fruit mass (MMF); early productivity (PP) (corresponding to the production obtained in the three first harvests) and mass of fruits per plant (MFP). 
The authors used average data of four plants in the plots of each treatment, for the nine traits evaluated. Initially, analysis of variance from the model was carried out, where the average and the effect of the treatment were considered fixed

$$
\mathrm{Y}_{\mathrm{ijk}}=\mu+\mathrm{g}_{\mathrm{i}}+\mathrm{b}_{\mathrm{k}}+\bar{\varepsilon}_{\mathrm{ijk}}
$$

Where, $\mathrm{Y}_{\mathrm{ijk}}=$ observation in $\mathrm{r}^{\text {th }}$ block, evaluated in the $\mathrm{i}^{\text {th }}$ genotype; $\mu=$ overall average of the experiment; $g_{i}=$ effect of the i genotype; $b_{k}=$ effect of $k$ block; $\overline{\varepsilon_{i j k}}=$ random error associated to $\mathrm{Y}_{\mathrm{ijk}}$ observation.

F-test was carried out and when a significant value was verified, the authors compared the average by ScottKnott test $(\mathrm{p} \leq 0.05)$ and the relative heterosis value of the ten triple hybrids in relation to the average of parents $(\mathrm{Hr} \%)$, using the following equation:

$$
\mathrm{H}_{r}=\left[\overline{\mathrm{F}}_{1}-\left(\frac{\overline{\mathrm{P}} 1+\overline{\mathrm{P}} 2}{2}\right) \times 100\right]
$$

The authors organized the averages of the analysis of variance, except the controls, and then diallel analysis was carried out. The analysis was carried out according to the method 2 model I of Griffing, adapted by Geraldi \& Miranda Filho (1988) for partial diallels. In this case, the statistical model used was according to the equation:

$$
Y_{i j}=\mu+1 / 2\left(d_{1}+d_{2}\right) g_{i}+g_{j}^{\prime}+s_{i j}+\overline{\varepsilon_{i j}}
$$

Where: $\mathrm{Y}_{\mathrm{ij}}=$ is the average value observed of the hybrid combination between the $\mathrm{i}^{\text {th }}$ line and the $\mathrm{j}^{\text {th }}$ tester; $\mu=$ overall average of the diallel; $d_{1}$, $\mathrm{d}_{2}=$ contrast involving group 1 and 2 averages and the overall average; $g_{i}=$ effect of general combining ability of the $i^{\text {th }}$ line; $g_{j}^{\prime}=$ effect of general combining ability of the $\mathrm{j}^{\text {th }}$ tester; $\mathrm{s}_{\mathrm{ij}}=$ effect of specific combining ability between line $\mathrm{i}$ and tester $\mathrm{j} ; \overline{\varepsilon_{\mathrm{ij}}}=$ average experimental error associated with the diallel.

\section{RESULTS AND DISCUSSION}

Considering fruit diameter, L6 line showed the highest value $(85.53 \mathrm{~mm})$, although this value did not significantly differ from L18 parents $(80.84 \mathrm{~mm})$, Atlantis $(80.73 \mathrm{~cm})$, the control Paloma $(80.81 \mathrm{~cm})$ and triple hybrids L6 x
ATL (82.64 mm), L6 x VAL (81.21 $\mathrm{mm}), \mathrm{L} 18 \times \mathrm{ATL}(81.23 \mathrm{~mm})$ and L18 $x$ VAL $(81.76 \mathrm{~mm})$. Heterosis for fruit diameter showed positive and negative combinations ranging from 5.36\% (L18 $\mathrm{x}$ VAL) to $-4.18 \%$ (L19 $\mathrm{x}$ ATL).

L1B, L6, L7, L18 and L19 lines, with average $79.25 \mathrm{~mm}$, showed the lowest fruit length, similarly to triple hybrid $1 B \times \operatorname{ATL}(80.94 \mathrm{~mm})$. Nine triple hybrids obtained by the combination of lines with Atlantis and Valdor showed a performance superior to the female parents and inferior to the respective male parents and controls Paloma and Impacto, these genotypes presenting the highest fruit length with average $113.31 \mathrm{~mm}$, not differing among them. The highest heterotic values for average fruit length were shown only by triple hibryds L19 x VAL (2.21\%) and L6 $\mathrm{x}$ ATL $(0.44 \%)$. For this same trait, González et al. (2004) found positive and much superior heterosis for all the crosses evaluated in relation to the values obtained in this work. Silva (2002) obtained similar data with other genotypes, though.

Length/diameter ratio is related to the fruit shape, considering that square-shaped fruits show ratio near 1. Elongated fruits, belonging to rectangular or conical groups, show ratio higher than 1 (Charlo et al., 2009). Currently, the Northeastern consumers have a preference for square and rectangular-shaped fruits. Thus, all the genotypes showed good fruit length/ diameter ratio. The authors highlight that Valdor (1.65) showed the highest value for this variable, differing from all the genotypes, showing that its fruits are more elongated. Heterosis was positive only for the triple hybrid L6 x ATL (1.28\%), expressing that this hybrid showed gain in relation to parents for this trait.

In relation to pulp thickness, no significant difference was found among genotypes, this trait ranging from 5.77 $\mathrm{mm}$ to $6.96 \mathrm{~mm}$. For triple hybrids, this result was expected, since the female and male parents used did not show differences among them for this trait. The heterosis found for pulp thickness ranged from $-4.52 \%$ to $9.77 \%$, the triple hybrids L7 x VAL (9.77\%) and
L19 x VAL (4.96\%) standing out. Pulp thickness, combined with traits such as fruit mass and length, is the productivity component with the highest increase in importance in sweet pepper crop. Therefore, this is a highly desirable trait in sweet pepper selection programs, most influenced by the additive gene effects. Besides, fruits which present a thicker pulp tend to be less malformed (Nascimento et al., 2010).

For number of locules per fruit, among classes, fruits with three to four locules prevailed. In fruit production, prevailing fruits with two to three locules, L7 line and triple hybrid L7 x ATL showed average of 2.92 and 3.17 locules, not differing among them. The highest values observed, prevailing fruits with three to four locules, were for the female parents L1B, L6 and L18, the male parent, the triple hybrids L1B x ATL, L1B x VAL, L6 x VAL, L7 $x$ VAL, L18 x VAL, L19 x ATL, L19 $x$ VAL and the commercial hybrids Paloma and Impacto, with average value 3.66 locules per fruit. These genotypes stood out considering that presence of four locules is one desirable trait in modern cultivars, since it is related to rectangular or square-shaped fruits. This uniform fruit shape facilitates packaging in boxes and on the shelves of supermarkets. Also, rectangular and square-shaped fruits are preferred by the local market. The heterosis values for number of locules per fruit were positive (Table 1), for triple hybrids L1B x ATL (5.12\%), L1B x VAL (0.40\%), L 7 x VAL (8.41\%), L18 x VAL (1.07\%), L19 x ATL (5.88\%) and L19 x VAL (2.77\%).

The values for number of fruits per plant ranged from 16.55 (Valdor) to 32.75 (L1B) among the genotypes (Table 2). The hybrid Valdor, despite showing the lowest number of fruits per plant, does not differ from Atlantis, L6, L19, from triple hybrids L6 x ATL, L6 $x$ VAL, L18 x ATL, L18 x VAL, L19 x ATL, L19 $x$ VAL and from the control Impacto, which showed an average of 21.60 fruits per plant. The L1B line, even having a higher value, did not differ from L7, L18, from the triple hybrids L1B x ATL, L1B x VAL, L7 x ATL, L7 x VAL and the controls Paloma and Rubia which showed an average of 25.68 
Table 1. Average values of four agronomic traits for seven sweet pepper genotypes used as parents in crosses, ten triple hybrids and three simple hybrids, followed by their heterosis value. Recife, UFRPE, 2013.

\begin{tabular}{|c|c|c|c|c|c|c|c|c|c|c|}
\hline Genotype & DF (mm) & $\begin{array}{l}\mathrm{Hr} \\
(\%)\end{array}$ & $\begin{array}{c}\mathrm{CF} \\
(\mathrm{mm})\end{array}$ & $\begin{array}{l}\mathrm{Hr} \\
(\%)\end{array}$ & C/D & $\begin{array}{l}\mathrm{Hr} \\
(\%)\end{array}$ & $\begin{array}{c}\mathbf{E P} \\
(\mathrm{mm})\end{array}$ & $\begin{array}{l}\mathrm{Hr} \\
(\%)\end{array}$ & NL & $\begin{array}{l}\mathrm{Hr} \\
(\%)\end{array}$ \\
\hline L 1B & $73.97 \mathrm{~b}$ & & $72.45 \mathrm{~d}$ & & $0.97 \mathrm{~d}$ & & 6.75 & & $3.52 \mathrm{a}$ & \\
\hline L 6 & $85.53 \mathrm{a}$ & & $83.21 \mathrm{~d}$ & & $0.97 \mathrm{~d}$ & & 5.91 & & $3.57 \mathrm{a}$ & \\
\hline L 7 & $74.14 \mathrm{~b}$ & & $80.06 \mathrm{~d}$ & & $1.08 \mathrm{~d}$ & & 6.41 & & $2.92 \mathrm{c}$ & \\
\hline L 18 & $80.84 \mathrm{a}$ & & $75.72 \mathrm{~d}$ & & $0.94 \mathrm{~d}$ & & 6.63 & & $3.57 \mathrm{a}$ & \\
\hline L 19 & $78.27 \mathrm{~b}$ & & $84.83 \mathrm{~d}$ & & $1.08 \mathrm{~d}$ & & 6.02 & & $3.35 \mathrm{~b}$ & \\
\hline L 1B x ATL & $74.58 \mathrm{~b}$ & -3.64 & $80.94 \mathrm{~d}$ & -11.67 & $1.08 \mathrm{~d}$ & -7.32 & 6.47 & 0.45 & $3.67 \mathrm{a}$ & 5.12 \\
\hline $\mathrm{L} 1 \mathrm{~B} \times \mathrm{VAL}$ & $73.32 \mathrm{~b}$ & -1.13 & $90.93 \mathrm{c}$ & -6.38 & $1.24 \mathrm{c}$ & -5.34 & 6.38 & -1.99 & $3.70 \mathrm{a}$ & 0.40 \\
\hline L $6 \times$ ATL & $82.64 \mathrm{a}$ & -0.58 & $97.14 \mathrm{~b}$ & 0.44 & $1.18 \mathrm{c}$ & 1.28 & 5.87 & -2.49 & $3.37 \mathrm{~b}$ & -3.98 \\
\hline L $6 \times$ VAL & $81.21 \mathrm{a}$ & 1.58 & $100.83 \mathrm{~b}$ & -1.64 & $1.23 \mathrm{c}$ & -6.10 & 6.16 & 1.14 & $3.57 \mathrm{a}$ & -3.77 \\
\hline L $7 \times$ ATL & $74.87 \mathrm{~b}$ & -3.31 & $89.69 \mathrm{c}$ & -5.72 & $1.20 \mathrm{c}$ & -1.63 & 6.36 & 1.43 & $3.17 \mathrm{c}$ & -0.47 \\
\hline L $7 \times$ VAL & $75.74 \mathrm{~b}$ & 2.00 & $94.05 \mathrm{c}$ & -6.82 & $1.24 \mathrm{c}$ & -9.15 & 6.96 & 9.77 & $3.67 \mathrm{a}$ & 8.41 \\
\hline L $18 \times$ ATL & $81.23 \mathrm{a}$ & 0.55 & $88.80 \mathrm{c}$ & -5.50 & $1.09 \mathrm{~d}$ & -5.21 & 6.44 & 0.94 & $3.37 \mathrm{~b}$ & -3.98 \\
\hline L $18 \times$ VAL & $81.76 \mathrm{a}$ & 5.36 & $94.02 \mathrm{c}$ & -4.80 & $1.15 \mathrm{c}$ & -11.19 & 6.32 & -2.01 & $3.75 \mathrm{a}$ & 1.07 \\
\hline L $19 \times$ ATL & $76.17 \mathrm{~b}$ & -4.18 & $89.44 \mathrm{c}$ & -8.28 & $1.17 \mathrm{c}$ & -4.09 & 5.80 & -4.52 & $3.60 \mathrm{a}$ & 5.88 \\
\hline L $19 \times$ VAL & $78.00 \mathrm{~b}$ & 2.20 & $105.61 \mathrm{~b}$ & 2.21 & $1.35 \mathrm{~b}$ & -1.09 & 6.45 & 4.96 & $3.70 \mathrm{a}$ & 2.77 \\
\hline Atlantis (ATL) & 80.73 a & & $110.21 \mathrm{a}$ & & $1.36 \mathrm{~b}$ & & 6.13 & & $3.45 \mathrm{~b}$ & \\
\hline Valdor (VAL) & $74.36 \mathrm{~b}$ & & $121.82 \mathrm{a}$ & & $1.65 \mathrm{a}$ & & 6.27 & & $3.85 \mathrm{a}$ & \\
\hline Paloma & $80.81 \mathrm{a}$ & & $108.39 \mathrm{a}$ & & $1.34 \mathrm{~b}$ & & 6.59 & & $3.77 \mathrm{a}$ & \\
\hline Rúbia & $75.77 \mathrm{~b}$ & & $104.03 \mathrm{~b}$ & & $1.37 \mathrm{~b}$ & & 6.17 & & $3.36 \mathrm{~b}$ & \\
\hline Impacto & $75.59 \mathrm{~b}$ & & $112.82 \mathrm{a}$ & & $1.48 \mathrm{~b}$ & & 5.77 & & $3.51 \mathrm{a}$ & \\
\hline
\end{tabular}

$\mathrm{DF}=$ average fruit diameter; $\mathrm{CF}=$ average fruit length; $\mathrm{C} / \mathrm{D}=$ fruit length/diameter ratio; $\mathrm{EP}=$ pulp thickness; $\mathrm{Hr}=$ heterosis in relation to the parents average. Means followed by same letter in column are not different by Scott Knott test 5\%.

fruits per plant. The heterotic value for the number of fruits per plant showed positive values for most triple hybrids. Especially the hybrid combinations L6 $\mathrm{x}$ ATL (14.85\%), L6 x VAL (12.29\%), L7 $x \operatorname{VAL}(14.99 \%)$, L18 x VAL (13.78\%) and L19 $x$ VAL (14.64\%). These values show a considerable increase when compared to the average of parents; however, this trait can contribute for a lower fruit production, a less thick pulp, and a lower productivity. Nevertheless, this relation also depends on the practices carried out for sweet pepper cultivation in protected environment (Melo, 1997).

For fruit mass, lines showed the lowest performance among the genotypes evaluated, except L6 which showed an average of $184.18 \mathrm{~g}$, not differing statistically from the triple hybrid L6 x VAL, $212.98 \mathrm{~g}$. Valdor showed average fruit mass of $251.54 \mathrm{~g}$ differing from all the genotypes (Table 2). The authors highlight that fruit mass can be altered according to number of fruits, considering that, in protected environment cultivation, fruit thinning is a common practice. Sweet pepper sprouting is dichotomous, thus, fruit production occurs in "layers". This reproductive characteristic makes sweet pepper a vegetable of multiple harvests. This way, the concentration of fruits in a certain layer interferes with subsequent production (Melo, 1997). The heterotic value was positive only for L1B $\mathrm{x}$ ATL with a $5.0 \%$ increase in relation to the average of parents. For the others, heterosis ranged from $-2.23 \%$ (L6 $\mathrm{x}$ VAL) to $-30.61 \%$ (L7 $x$ VAL). These negative values for heterosis occurred because most lines presented low performance.

For early productivity, L7, L18, L19, the controls, the triple hybrids L1B $\mathrm{x}$ ATL, L7 x ATL, L18 x ATL and L18 $x$ VAL showed the lowest values (average $1.17 \mathrm{~kg} /$ plant), corresponding to $44.89 \%$ of total production, not differing among them. On the other hand, L1B, L6, Atlantis, Valdor, the triple hybrids L1B x VAL, L6 x ATL, L6 x VAL, L7 $x$ VAL, L19 x ATL and L19 x VAL did not differ among them, showing, in average, early productivity of 1.44 $\mathrm{kg} / \mathrm{plant}$, corresponding to $45.28 \%$ of total production. High values for early production can have a fast economic effect for the producer, and possibly can be incorporated to the sweet pepper productive system. The heterosis values for early production ranged from $-8.69 \%$ to $16.33 \%$. The triple hybrids L6 $\mathrm{x}$ ATL (2.87\%), L6 x VAL (6.22\%), L18 $x \operatorname{ATL}(4.80 \%), \operatorname{L} 19 \times$ ATL $(16.33 \%)$ and L19 x VAL (3.59\%) stood out due to positive heterosis compared to the parents average.

For mass of fruits per plant, Valdor $(4.15 \mathrm{~kg} / \mathrm{plant})$ and the triple hybrid L6 x VAL (4.16 kg/plant) stood out, not differing statistically among them. On 
Table 2. Average values of four agronomic traits for seven sweet pepper genotypes used as parents in crosses, ten triple hybrids and three simple hybrids, followed by their heterosis value. Recife, UFRPE, 2013.

\begin{tabular}{|c|c|c|c|c|c|c|c|c|}
\hline Genotype & NFP & $\operatorname{Hr}(\%)$ & MMF (g) & $\operatorname{Hr}(\%)$ & $\begin{array}{c}\text { PP } \\
\text { (kg/plant) }\end{array}$ & $\operatorname{Hr}(\%)$ & $\begin{array}{c}\text { MFP } \\
\text { (kg/plant) }\end{array}$ & $\operatorname{Hr}(\%)$ \\
\hline L 1B & $32.75 \mathrm{a}$ & & $78.01 \mathrm{~d}$ & & $1.32 \mathrm{a}$ & & $2.41 \mathrm{c}$ & \\
\hline L 6 & $18.50 \mathrm{~b}$ & & $184.18 \mathrm{~b}$ & & $1.42 \mathrm{a}$ & & $3.37 \mathrm{~b}$ & \\
\hline $\mathrm{L} 7$ & $28.93 \mathrm{a}$ & & $97.18 \mathrm{~d}$ & & $1.08 \mathrm{~b}$ & & $2.80 \mathrm{c}$ & \\
\hline L 18 & $21.68 \mathrm{~b}$ & & $81.20 \mathrm{~d}$ & & $0.93 \mathrm{~b}$ & & $1.73 \mathrm{~d}$ & \\
\hline L 19 & $23.68 \mathrm{~b}$ & & $110.29 \mathrm{~d}$ & & $1.15 \mathrm{~b}$ & & $2.50 \mathrm{c}$ & \\
\hline L $1 \mathrm{~B} \times \mathrm{ATL}$ & $25.81 \mathrm{a}$ & -7.32 & $116.32 \mathrm{c}$ & 5.00 & $1.22 \mathrm{~b}$ & -8.69 & $2.95 \mathrm{~b}$ & 4.49 \\
\hline L $1 B \times$ VAL & $25.37 \mathrm{a}$ & 2.92 & $119.23 \mathrm{c}$ & -27.64 & $1.40 \mathrm{a}$ & -5.08 & $3.02 \mathrm{~b}$ & -7.92 \\
\hline L $6 \times$ ATL & $23.81 \mathrm{~b}$ & 14.85 & $137.20 \mathrm{c}$ & -16.45 & $1.43 \mathrm{a}$ & 2.87 & $3.24 \mathrm{~b}$ & -2.11 \\
\hline L $6 \times$ VAL & $19.68 \mathrm{~b}$ & 12.29 & $212.98 \mathrm{~b}$ & -2.23 & $1.62 \mathrm{a}$ & 6.22 & $4.16 \mathrm{a}$ & 10.63 \\
\hline L $7 \times$ ATL & $26.31 \mathrm{a}$ & 1.40 & $94.38 \mathrm{~d}$ & -21.82 & $1.20 \mathrm{~b}$ & -1.63 & $2.48 \mathrm{c}$ & -18.01 \\
\hline L $7 \times$ VAL & $26.15 \mathrm{a}$ & 14.99 & $120.98 \mathrm{c}$ & -30.61 & $1.33 \mathrm{a}$ & -1.84 & $3.12 \mathrm{~b}$ & -10.21 \\
\hline L $18 \times$ ATL & $23.50 \mathrm{~b}$ & 5.28 & $105.04 \mathrm{~d}$ & -6.82 & $1.20 \mathrm{~b}$ & 4.80 & $2.45 \mathrm{c}$ & -1.60 \\
\hline L $18 \times$ VAL & $21.75 \mathrm{~b}$ & 13.78 & $158.28 \mathrm{c}$ & -4.86 & $1.24 \mathrm{~b}$ & -3.12 & $3.46 \mathrm{~b}$ & 17.68 \\
\hline L $19 \times$ ATL & $22.37 \mathrm{~b}$ & -4.07 & $97.33 \mathrm{~d}$ & -23.53 & $1.46 \mathrm{a}$ & 16.33 & $2.17 \mathrm{~d}$ & -24.52 \\
\hline L $19 \times$ VAL & $23.06 \mathrm{~b}$ & 14.64 & $128.79 \mathrm{c}$ & -28.81 & $1.44 \mathrm{a}$ & 3.59 & $2.93 \mathrm{~b}$ & -11.87 \\
\hline Atlantis (ATL) & $22.96 \mathrm{~b}$ & & $144.28 \mathrm{c}$ & & $1.36 \mathrm{a}$ & & $3.25 \mathrm{~b}$ & \\
\hline Valdor (VAL) & $16.55 \mathrm{~b}$ & & $251.54 \mathrm{a}$ & & $1.63 \mathrm{a}$ & & $4.15 \mathrm{a}$ & \\
\hline Paloma & $25.18 \mathrm{a}$ & & $135.16 \mathrm{c}$ & & $1.21 \mathrm{~b}$ & & $3.38 \mathrm{~b}$ & \\
\hline Rúbia & $26.00 \mathrm{a}$ & & $126.25 \mathrm{c}$ & & $1.29 \mathrm{~b}$ & & $3.23 \mathrm{~b}$ & \\
\hline Impacto & $24.07 \mathrm{~b}$ & & $139.74 \mathrm{c}$ & & $1.22 \mathrm{~b}$ & & $3.28 \mathrm{~b}$ & \\
\hline
\end{tabular}

$\mathrm{NFP}=$ number of fruits per plant; $\mathrm{MMF}=$ average mass of fruits; $\mathrm{PP}=$ early production; $\mathrm{MFP}=$ average mass of fruits per plant; $\mathrm{Hr}=$ heterosis in relation to the parents average. Means followed by same letter in column are not different by Scott Knott 5\%.

the other hand, L18 and the triple hybrid L19 x ATL did not differ and showed the worst performance for mass of fruits per plant, $1.73 \mathrm{~kg} / \mathrm{plant}$ and $2.17 \mathrm{~kg} / \mathrm{plant}$, respectively. The average fruit yield obtained with the simple hybrid Valdor and with the triple hybrid L6 $x$ VAL in the present research exceeded the ones found in literature (Queiroga et al., 2002; Factor, 2003; Fontes et al., 2005), showing that such genotypes can be used in protected environment, since the productivities observed were high. The heterosis values were positive for L1B $x \operatorname{ATL}(4.49 \%)$, L6 x VAL (10.63\%) and L18 x VAL (17.68). Generally, a great variation of heterosis estimates in relation to the parents, presenting positive values, considerably favorable considering the increase of mass of fruits per plant, was observed.

L1B (4.12 mm) and L7 (0.98 mm) lines showed higher estimates of GCA contributing to an increase in relation to fruit length. Hybrids of L1B and L7 lines produced fruits about $2.55 \mathrm{~mm}$ longer than the average of lines (Table 3 ).

L1B and L 7 lines showed the highest estimates of GCA for fruit length/ diameter ratio $(0.07 \mathrm{~mm})$ and $\mathrm{L} 7(0.01$ $\mathrm{mm})$, as well as for number of fruits per plant (1.40) and L7 (0.79). This fact shows that these parents are favorable for increasing size and number of fruits per plant, respectively.

The authors verified that, for number of locules, L1B (0.07), L6 (0.10) and L18 $(0.01)$ showed positive values of GCA providing a contribution for increasing the number of locules, which would be desirable in sweet pepper fruits, as fruits with 3 to 4 locules are more valued by the market. On the other hand, L7 and L19 parents showed negative values of
GCA, reducing the number of locules, when in hybrid combinations.

L1B, L6 and L7 lines showed the greatest GCA effects for mass of fruits per plant, mass of fruits and early production, respectively, $0.10 \mathrm{~kg} / \mathrm{plant}$, $6.57 \mathrm{~g}, 0.08 \mathrm{~kg} /$ plant for L1B line; 0.18 $\mathrm{kg} / \mathrm{plant}, 15.25 \mathrm{~g}$ and $0.06 \mathrm{~kg} / \mathrm{plant}$ for L6 line and $0.23 \mathrm{~kg} / \mathrm{plant}, 5.35 \mathrm{~g}, 0.02$ $\mathrm{kg} / \mathrm{plant}$ for L7 line. This fact allows inferring that a substantial increase in these production components might have occurred in crosses in which these parents participate. The other parent lines showed negative values of $g_{i}$ for the three traits, the highest value being $-0.42 \mathrm{~kg} /$ plant for mass of fruits per plant, $-22.44 \mathrm{~g}$ for average fruit mass and $-0.11 \mathrm{~kg} / \mathrm{plant}$ for early production, both from L18 parent, which contributed for reducing the importance of these traits in crosses which this parent 
Table 3. Lines general combining ability (GCA Lines), testers general combining ability (GCA Testers) and specific combining ability among hybrids from lines and testers (SCA LxT) for nine agronomic traits of 17 sweet pepper genotypes. Recife, UFRPE, 2013.

\begin{tabular}{|c|c|c|c|c|c|c|c|c|c|}
\hline Parameter & DF & $\mathbf{C F}$ & $\mathbf{C} / \mathbf{D}$ & EP & NL & MMF & PP & NFP & MFP \\
\hline \multicolumn{10}{|c|}{ General combining ability (Lines) (gi) } \\
\hline$g_{1}$ L1B & -1.69 & 4.12 & 0.07 & 0.08 & 0.07 & 6.57 & 0.08 & 1.40 & 0.10 \\
\hline$g_{2}$ L6 & 0.96 & -2.31 & -0.03 & -0.11 & 0.10 & 15.25 & 0.06 & -1.40 & 0.18 \\
\hline $\mathrm{g}_{3} \mathrm{~L} 7$ & -0.17 & 0.98 & 0.01 & -0.08 & -0.18 & 5.35 & 0.02 & 0.79 & 0.23 \\
\hline$g_{4} \quad L 18$ & -0.15 & -2.83 & -0.03 & 0.20 & 0.01 & -22.44 & -0.11 & -0.12 & -0.42 \\
\hline$g_{5}$ L19 & 1.05 & 0.046 & -0.01 & -0.09 & -0.01 & -4.74 & -0.05 & -0.66 & -0.11 \\
\hline \multicolumn{10}{|c|}{ General combining ability (Testers) (gj) } \\
\hline $\mathrm{g}_{1}$, Atlantis & 0.22 & -3.73 & -0.05 & -0.11 & -0.09 & -18.26 & -0.04 & 0.63 & -0.28 \\
\hline $\mathrm{g}_{2}$, Valdor & -0.22 & 3.73 & 0.05 & 0.11 & 0.09 & 18.26 & 0.04 & -0.63 & 0.28 \\
\hline \multicolumn{10}{|c|}{ Specific combining ability } \\
\hline $\mathrm{s}_{1.1}, \mathrm{~L} 1 \mathrm{~B} \times \mathrm{ATL}$ & 4.23 & 16.05 & 0.13 & -0.14 & -0.07 & 22.45 & -0.03 & -2.53 & 0.44 \\
\hline $\mathrm{s}_{1.2}, \mathrm{~L} 1 \mathrm{~B} \times \mathrm{VAL}$ & -1.68 & 20.19 & 0.31 & -0.23 & 0.13 & 93.19 & 0.15 & -7.66 & 0.77 \\
\hline $\mathrm{s}_{2.1}, \mathrm{~L} 6 \times \mathrm{ATL}$ & -4.56 & -6.77 & -0.02 & 0.40 & 0.12 & -14.18 & -0.14 & 3.12 & 0.05 \\
\hline $\mathrm{s}_{2.2}, \mathrm{~L} 6 \times \mathrm{VAL}$ & -5.38 & -4.25 & 0.02 & 0.07 & -0.04 & -47.79 & -0.05 & 3.96 & -0.43 \\
\hline $\mathrm{s}_{3.1}, \mathrm{~L} 7 \times \mathrm{ATL}$ & 4.63 & 6.12 & 0.01 & -0.22 & 0.10 & 16.58 & 0.10 & -1.07 & 0.30 \\
\hline $\mathrm{s}_{3.2}, \mathrm{~L} 7 \mathrm{x} \mathrm{VAL}$ & 3.64 & 2.34 & -0.03 & -0.17 & 0.11 & 55.84 & 0.21 & -3.92 & 0.65 \\
\hline $\mathrm{s}_{4.1}, \mathrm{~L} 18 \times \mathrm{ATL}$ & -3.16 & 2.48 & 0.08 & -0.02 & -0.29 & 1.56 & 0.01 & 2.34 & 0.19 \\
\hline $\mathrm{s}_{4.2}, \mathrm{~L} 18 \mathrm{x}$ VAL & -1.85 & -0.61 & 0.01 & 0.33 & 0.01 & -8.34 & 0.05 & 3.46 & 0.27 \\
\hline $\mathrm{s}_{51}, \mathrm{~L} 19 \times$ ATL & 1.99 & -1.28 & -0.04 & 0.35 & -0.06 & -5.45 & -0.03 & 0.06 & -0.13 \\
\hline $\mathrm{s}_{5.2}, \mathrm{~L} 19 \mathrm{x}$ VAL & 2.96 & -3.53 & -0.09 & -0.003 & 0.12 & 11.25 & -0.09 & -0.40 & 0.30 \\
\hline
\end{tabular}

$\mathrm{DF}=$ Average fruit diameter; $\mathrm{CF}=$ average fruit length; $\mathrm{C} / \mathrm{D}=$ Fruit length/diameter ratio; $\mathrm{EP}=$ pulp thickness; $\mathrm{NL}=$ number of locules per fruit; $\mathrm{MMF}=$ average fruit mass; $\mathrm{PP}=$ early production; $\mathrm{NFP}=$ number of fruits per plant; $\mathrm{MFP}=$ average mass of fruits per plant.

participated.

The authors verified clear superiority of Valdor in the effects of GCA of the testers. This hybrid can provide the best segregating populations for most traits.

SCA effect is interpreted as a deviation of a certain hybrid in relation to what was expected based on the GCA of its parents. Thus, the most favorable hybrid is that one presenting a higher estimate of specific combining ability, in which one of the parents shows the highest general combining ability. Highest values are for the most dissimilar genotypes in the frequencies of genes with dominance, though they are also influenced by the low average gene frequency of the diallel (Gomes et al., 2000).

For fruit diameter L7 x ATL (4.63 $\mathrm{mm}$ ) and L1B x ATL (4.23 mm) showed the highest values of SCA. L1B and L7 parents showed behavior contrary to the expected, since they showed negative
GCA, with a greater importance of non-additive interactions, resulting from allelic combination with the tester Atlantis which showed positive GCA. This also happens with L19 line and hybrid tester Valdor.

L1B x VAL combination showed the highest SCA value for average fruit length $(20.19 \mathrm{~mm})$. L1B and Valdor parents showed the greatest GCA effects, showing that, for these combinations, the additive gene effects were more important. Being genetically superior, they will provide satisfactory gains through selecting individuals over segregating generations. For the Atlantis tester, which showed negative GCA estimates and positive SCA estimates, an allelic complementation could be noticed.

The highest SCA values for fruit length/diameter ratio were observed in hybrids L1B x VAL (0.31) and L1B $x$ ATL (0.13), followed by L18 x ATL
(0.08) and L6 x VAL (0.02). The other triple hybrids showed low estimates of SCA.

The SCA estimates for pulp thickness, number of locules and early production were not discussed since these traits did not show any significant result for the partial diallel analysis of variance and F-test (5\%) (Table 3).

L6 $x$ VAL combination showed the highest SCA value for number of fruits per plant (3.96 fruits), followed by the triple hybrids L18 x VAL, L6 $\mathrm{x}$ ATL and L18 x ATL, with values of 3.46, 3.12 and 2.34 fruits, respectively. The authors highlight that L6 and L18 parent lines and the tester Valdor showed negative effects of GCA, showing that for these combinations, non-additive gene effects were more important, and allelic complementation among the parents could be verified.

The highest positive values of SCA estimates for average mass of fruits were 
observed for L1B x VAL (93.19 g) and L7 x VAL (55.84 g), followed by L1B x ATL (22.45 g), L7 x ATL (16.58 g) and L19 x VAL (11.25 g). The L1B (6.57 g) and L18 (5.35 g) lines and Valdor (18.26 g) showed one of the highest values of GCA estimates. This fact means that, as parents, those genotypes can provide gains in crosses in which they participate due to the accumulation of genes with additive effect for mass of fruits. On the other hand, L6 line showed the highest values of GCA estimates; however, in hybrid combinations with both testers, the lowest SCA estimates were expressed, showing low allelic complementation among the parents. According to Miranda Filho \& Gorgulho (2001), SCA is interpreted as an effect in hybrid expression which is additional to GCA effects. The hybrid expression can be better or worse depending on the effect expected based on GCA.

The results of SCA for mass of fruits per plant showed that the hybrids L1B x $\operatorname{VAL}(0.77 \mathrm{~kg} /$ plant $)$ and $\mathrm{L} 7 \mathrm{x} \operatorname{VAL}(0.65$ $\mathrm{kg} /$ plant) stood out with the highest values, whose parents were considered good general combiners, with the highest estimates of GCA. In contrast, when the authors crossed these hybrids with Atlantis of negative $g_{i}$ estimate, they showed positive values of SCA $(0.44$ $\mathrm{kg} /$ plant and $0.30 \mathrm{~kg} /$ plant), showing the action of genes which increased the character expression. According to Cruz et al. (2012), SCA is, in large part, dependent on genes which show effects of dominance and overdominance, evidencing the importance of the nonadditive effect genes resulting from allelic complementation among the parents.

GCA estimates of lines and testers, for all the genotypes and all the traits evaluated, show a wide variation in the diallel components. This finding reinforces that a breeder must pay close attention to the proper selection of parents in a breeding program, even more when the purpose is to improve several traits simultaneously.

In any case, breeders should prefer parents which show a higher GCA for the main traits related to the crop economic value. According to the results obtained, Valdor showed the best ability to combine with lines, showing to be a good tester. The same way, L1B, L6 and L7 lines showed the highest GCA values for the most of traits; this fact means that they are viable to be used in crosses, since they tend to provide a greater accumulation of genes with favorable additive effect. These lines can be considered important when establishing a base population. Furthermore, they will provide satisfactory gains by the selection of genetically superior individuals over segregating generations.

\section{REFERENCES}

BERNARDO, R. 2003. Breeding for quantitative traits in plants. Woodbury: Stemma Press, 369p.

BLAT, SF; BRAZ, LT; ARRUDA, AS. 2007. Avaliação de híbridos duplos de pimentão. Horticultura brasileira 25: 350-354.

BORÉM, A; MIRANDA, GV.2013. Melhoramento de plantas. 6 ed. Viçosa: UFV. 523p.

CARVALHO, SIC; BIANCHETTI, LB; HENZ, GP. 2003. Germplasm collection of Capsicum spp. maintained by Embrapa Hortaliças (CNPH). Capsicum and Eggplant Newsletter. 22: 17-20.

CHARLO, HCO; CASTOLDI, R; FERNANDES, C; VARGAS, PF; BRAZ, LT. 2009. Cultivo de híbridos de pimentão amarelo em fibra da casca de coco. Horticultura Brasileira. 27: 155-159.

CRUZ, CD; REGAZZI, AJ; CARNEIRO, PCS. 2012. Modelos biométricos aplicados ao melhoramento genético. 4.ed. Viçosa: UFV. 480p.

FACTOR, TL. 2003. Utilização do efluente de biodigestor no cultivo de pimentão em substratos, sob ambiente protegido. Jaboticabal: UNESP-FCAV. 88p (Dissertação de mestrado).

FONTES, PCR; DIAS; EN; SILVA; DJH. 2005. Dinâmica do crescimento, distribuição de matéria seca na planta e produção de pimentão em ambiente protegido. Horticultura Brasileira. 23: 94-99.

FURLANI, PR; BOLONHEZI; D; SILVEIRA, LCP; FAQUIN, V. 1999. Nutrição mineral de hortaliças, preparo e manejo de soluções nutritivas. Informe Agropecuário, Belo Horizonte, v.20, n.200/201, 90-98p.

GERALDI, IO; MIRANDA FILHO, JB. 1988. Adapted models for the analysis of combining ability of arieties in partial diallel crosses. Revista Brasileira de Genética. 11: 419-430.

GOMES, MS; PINHO, EVR; PINHO, RGV; VIEIRA, MGGC. 2000. Estimativas da capacidade de combinação de linhagens de milho tropical para qualidade fisiológica de sementes. Ciência e Agrotecnologia. 24: 41-49.

GOMIDE, ML; MALUF, WR; GOMES, LAA. 2003. Heterose e capacidade combinatória de linhagens de pimentão (Capsicum annuum L.). Ciência e Agrotecnologia. 27: 1007-1015.

GONZÁLEZ, JRAD; ZAMBRANO, GM; MERAZ, MR; LOERA, AR; CAMPODÓNICO, OP. 2004. Efectos genéticos y heterosis de caracteres de calidad comercial em chile Serrano. In: Primera Convención Mundial Del Chile. Relatório. 21-24p.

HOLLAND, JB. 2001. Epistasis and plant breeding. Plant Breeding Reviews. 21: 21-92.

MELO, AMT. 1997. Análise genética de caracteres de fruto em híbridos de pimentão. Piracicaba: ESALQ. 112p (Tese doutorado).

MIRANDA FILHO, JB; GORGULHO, EP. 2001. Cruzamentos com testadores e dialelos. In: NASS, LL; VALOIS, ACC; MELO, IS; VALADARES, MC. (eds). Recursos genéticos e melhoramento de plantas. Rondonópolis: Fundação MT, 650-671p.

NASCIMENTO, IR; MALUF, WR; FARIA, MV; VALLELA, C; RESENDE, JD; NOGUEIRA, DW. 2010. Capacidade combinatória de linhagens de pimentão a partir de análise dialélica multivariada. Acta Scientiarum Agronomy. 32: 235-240.

QUEIROGA, RCF; NOGUEIRA, ICC; BOTELHO NETO, F; MOURA, ARB; PEDROSA, JF. 2002. Utilização de diferentes materiais como cobertura morta do solo no cultivo de pimentão. Horticultura Brasileira. 20: 416-418.

SILVA, LL. 2002. Heterose e capacidade de combinação em cruzamentos dialélicos parciais de pimentão. Piracicaba: ESALQ. 82p (Tese doutorado). 